\title{
A Comparative Study of Various Indices for Extraction Urban Impervious Surface of Landsat 8 OLI
}

\author{
Iswari Nur Hidayati ${ }^{1,2^{*}}$, R. Suharyadi ${ }^{1,2}$ \\ ${ }^{1}$ Department of Geography Information Science, Faculty of Geography, University of Gadjah Mada \\ ${ }^{2}$ Remote Sensing Laboratory, Faculty of Geography, University of Gadjah Mada \\ *) Corresponding Author (e-mail: iswari@ugm.ac.id)
}

Received: 06 November 2019/ Accepted: 23 December 2019/ Published: 27 December 2019

\begin{abstract}
Impervious surface areas are developing relatively rapidly in urban environments. This increase in area is caused by the conversion of vegetation to urban built land; its expansion is straightlined, with decreasing green spaces in urban areas. The impervious surface is one indicator for detecting urban heat islands. This study compares various indices for mapping impervious surfaces using Landsat 8 OLI imagery by optimizing its different spectral characteristics. The research objectives are (1) to apply various indices to impervious surface mapping and (2) to identify impervious surfaces in urban areas based on multiple indices and to provide the best combination indices and methods recommendations, The maximum likelihood classifier is used for land use detection, as it separates built up and non-built up urban areas. As a result, BCI (Biophysical Composition Index) has the highest value when compared to NDVI, NDBI, EBBI, SAVI, and NDISI. BCI has the most significant impervious surface index, as evidenced by the most significant correlation coefficient. The study concludes that $\mathrm{BCI}$ is the most useful index for categorizing impervious surfaces into bare land, residential areas or vegetation.
\end{abstract}

Keywords: impervious surface mapping, urban area, urban heat island

\begin{abstract}
Abstrak
Permukaan kedap air merupakan area pengkerasan sebagai satu jenis tutupan lahan utama lingkungan perkotaan dan pinggiran kota. Konversi lahan pertanian dan area vegetasi menjadi penggunaan lahan perkotaan dan pinggiran kota secara langsung berkaitan dengan peningkatan luas permukaan kedap air. Pemekaran wilayah impervious surface perkotaan mengakibatkan menurunnya ruang terbuka hijau public dan menjadi salah satu indikator urban heat island. Studi ini membandingkan berbagai indeks untuk memetakan permukaan kedap air menggunakan citra Landsat 8 OLI dengan mengoptimalkan berbagai karakteristik spektral dari citra Landsat 8 OLI. Tujuan penelitian adalah (1) untuk menerapkan berbagai indeks untuk pemetaan impervious surface dan (2) Penelitian ini juga mengidentifikasi permukaan yang tidak tembus air di daerah perkotaan berdasarkan berbagai indeks dan memberikan rekomendasi serta menemukan indeks terbaik untuk memetakan permukaan yang tidak tembus air di daerah perkotaan. Selain menggunakan indeks, metode klasifikasi pengawasan penggunaan lahan, klasifikasi kemungkinan maksimum yang digunakan untuk mengekstraksi area built-up, dan non-built-up. Penilaian akurasi penelitian ini menggunakan pengumpulan data lapangan dengan untuk menghitung koefisien kappa dan akurasi pemetaan. Hasil penelitian menunjukkan bahwa BCI merupakan indeks terbaik untuk ekstraksi permukaan kedap air di perkotaan.
\end{abstract}

Kata kunci: permukaan kedap air, pulau bahang, area perkotaan 


\section{Introduction}

Impervious surfaces have been a significant area of research due to the urban heat island phenomenon and climate change (Wu, Zhang, \& Zang, 2019). One assessment of the urban environment uses the impervious surface indicator (Li, Lu, \& Kuang, 2016). The complexity of impervious surface research poses a challenge in selecting methods to improve mapping evaluation results. In urban areas, the biophysical environment consists of open land, vegetation areas, and built-up land. Impervious surfaces in urban areas can be found, for example, in roads, parking lots, or areas that do not allow rainwater to infiltrate the soil. Impervious surfaces have long been studied as a significant variable in urban areas, especially in urban planning and environmental studies. Research on urban impervious surfaces usually includes urban climate, air, and water quality factors (Deng et al., 2013). Research methodologies that have been employed in relation to impervious surfaces include the land use approach (Sharma, Ghosh, \& Joshi, 2013) and accessing the population ( $\mathrm{Lu} \mathrm{\&}$ Weng, 2006). Urban planning and land use approaches (Chen \& Yu, 2016; Xiao et al., 2018), urban green space planning (Zhang et al., 2017) and also urban environmental assessment (Liu et al., 2019; Trivero et al., 2012) have been used in urban impervious surface research.

Sinha et al. (2016) found that urban builtup land applies high reflection on SWIR and TIR wavelengths and low reflection on NIR. Built-up land reflectance on the SWIR band is higher than the NIR wavelength (Weng \& Lu, 2008). Using NDVI (Normalized Difference Vegetation Index)for vegetation data extraction, from high-resolution imagery until medium resolution, always performed with high correlation, and also using the same spectral characteristic to find the best combination index (Jawak \& Luis, 2013; Walker et al., 2014). NDWI (Normalized Difference Water Index) was introduced by McFeeters (2013), and is utilized to measure surface water in a specific area. NDWI can detect surface water cover.
$\mathrm{Xu}$ (2006) improved the drawbacks of NDWI by modifying it with the inclusion of medium infrared bands, known as MDNWI (Modified Difference Water Index). The replacement of NIR (near-infrared wavelength) by MIR (middle infrared wavelength) will reduce urban built-up land, which has a positive value on NDWI, resulting in a negative amount on MNDWI. NDISI (Normalized Difference Impervious Index) is constructed to maximize the heat radiation emitted by soil reflection involving thermal waves, minimizing vegetation reflection on the NIR, MIR, and VIS wavelengths, and maximizing soil and sand reflection on the MIR wavelength.

Land Surface Temperature (LST) plays a significant role in research on climate, air temperature, and the urban environment on local and global scales. Various methods for detecting urban heat island phenomena often use visual data interpretation, spectral-based applications (Liu et al., 2015), and spatial modeling (Shirani-bidabadi et al., 2019). Land surface temperature is one indicator of the urban heat island phenomenon. Zhang et al. (2016) found that to increase accuracy, dualpolarimetric SAR data should be used. Spectral mixture analysis (SMA) is another method that has been used for identifying impervious surfaces in urban areas. Parece and Campbell (2013) also showed that Landsat imagery is useful in analyzing such surfaces. Impervious surface identification techniques employ supervised classification, such as maximum likelihood, parallel-piped classification, the Mahalanobis classifier, and the minimum distance to mean classifier. Many studies of impervious surface estimation and mapping have used high spatial resolution (Chen et al., 2019; Huang et al., 2019) and medium spatial resolution (Liu et al., 2019). Regional complexity means that research using medium resolution imagery produces reliable data. In several previous studies, impervious surface data extraction has often employed remote sensing data, including regression methods, artificial neural networks, and classification 
both digitally and visually. Visual and digital classification are complicated methods, as they require high dealing with determining the training area and should involve a high degree of interpreter subjectivity.

Indices provide ease and convenience in processing because each index has different values and information. The sample must also represent all land-use features. The sample collection must be conducted carefully and spread over the research area. Nevertheless, impervious surface areas are often overvalued in less-developed regions such as low-intensity built-up ones, caused by the mixed pixels in areas with bright impervious objects (Li et al., 2016). A practical and automatic approach to measuring and mapping in impervious surfaces from medium spatial resolution imagery is highly recommended. Some built-up indices have been developed, such as NDBI and EBBI.

Besides considering previous research, this paper also analyzed the techniques for enhancing the extraction of impervious surfaces data using various indices. Urban morphology based on thermal phenomena was compared with multiple indices in cities. However, the problem that arises is the merger between built-up and open land, which means the index is unable to detect surface-resistant surfaces with vegetation cover ( $\mathrm{Xu}$ et al., 2018). Bare land spectral responses, impervious surfaces, and urban spectral characteristics are different. This study compares various indices to choose the best

\section{Research Method}

The remote sensing data used in the study was obtained from Landsat 8 OLI with path/ row 120/65, acquisition date 7 September 2017 from Yogyakarta urban areas (Figure 1). Landsat 8 has two main instruments onboard, Operational Land Imager (OLI) and the Thermal Infrared Sensor (TIRS), both with an approximate swath of $180 \mathrm{~km}$ and a radiometric resolution of 12 bits. Landsat 8 OLI was used for various extraction indices in this research. Before conducting the indexing process, radiometric correction must be correctly performed. This converts digital number values to radiance values using the bias and gain values, then turns the radiance values to ToA references. This research involves various indices, such as NDBI (Normalized Difference Built-up Index), EBBI (Enhanced Built-up and Bareness Index), NDVI (Normalized Difference Vegetation Index), SAVI (Soil Adjusted Vegetation Index), and NDISI (Normalized Difference Impervious Surface Surface Index) to achieve the best accuracy in the impervious surface mapping.

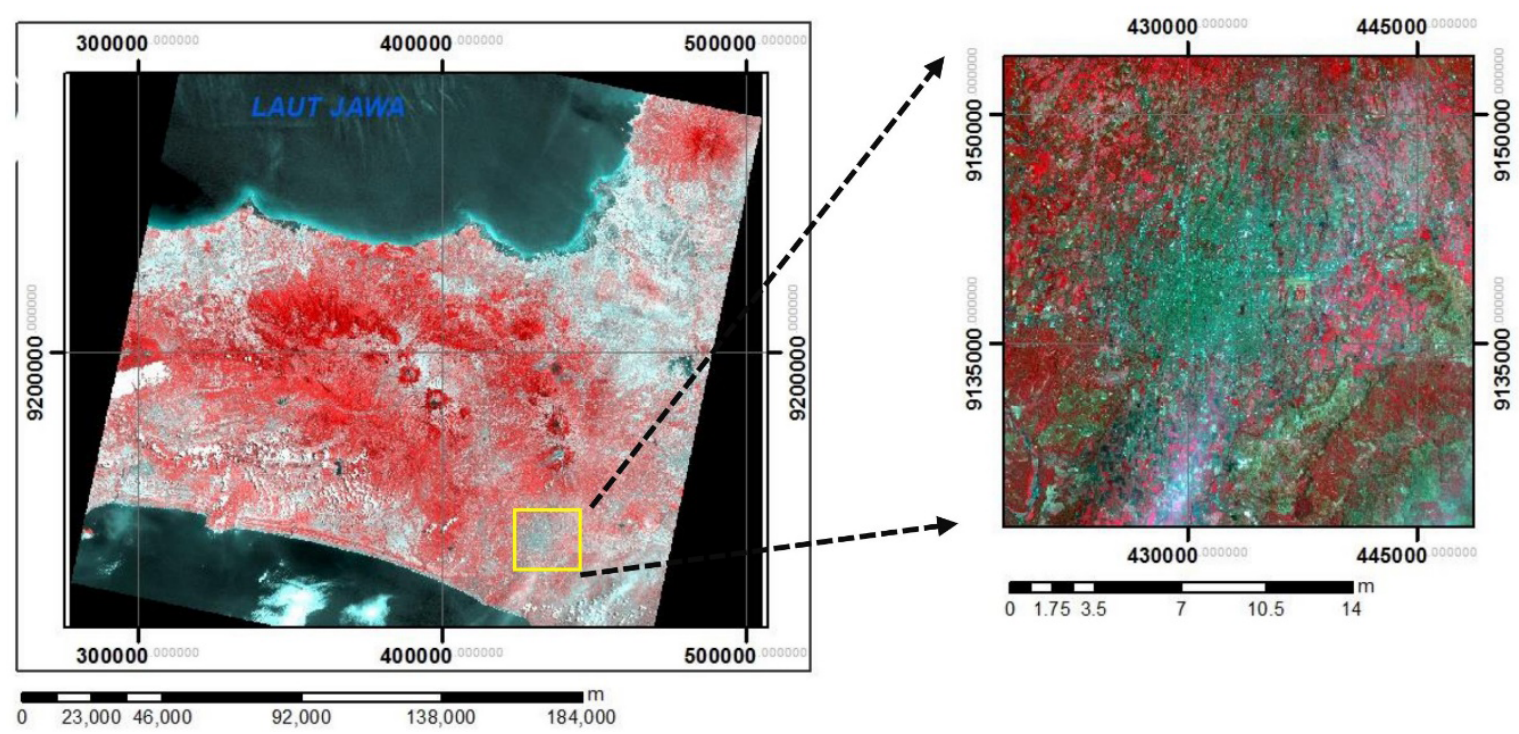

Figure 1. Yogyakarta Urban Area 


\subsection{Processing and Indexing}

An index is a simple graphical indicator that can be used to analyze remote sensing data. The band combinations of Landsat 8 are needed to create an image index and maximum likelihood classification. Knowing the differentiating to establish the differences in urban infrastructure, digital image extracting techniques were applied to the Landsat 8 Imagery. The normalized difference formula, which used maximum and minimum reflectance impervious indices, resulted in 64 combination indices of the Landsat imagery. Apart from the normalized index, this research also uses indices that were employed in previous research.

1) Normalized Difference Impervious Index. The impervious surface was raised by using two bands, the visible and the thermal. VIS refers to the visible bands, such as bands 2,3,4, while TIR1 is thermal infrared band 8 of the Landsat 8 Imagery. The range value of this index is from -1 to +1 .

$$
N D I I=\frac{V I S-T I R 1}{V I S+T I R 1}
$$

2) Normalized Difference Built-up Index. To create the NDBI formula, bands 6 (SWIR1) and 5 (Near Infrared of Landsat 8 OLI) were used.

$$
N D B I=\frac{S W I R 1-N I R}{S W I R 1+N I R}
$$

3) Normalized Difference Impervious Surface. Using DN values, the formula for calculating NDISI using Landsat 8 imagery is:

$$
N D I S I=\frac{T I R 1-\left[\frac{M N D W I+N I R+S W I R 1}{3}\right]}{\operatorname{TIR} 1+\left[\frac{M N D W I+N I R+S W I R 1}{3}\right]}
$$

4) SAVI (Soil Adjusted Vegetation Index). SAVI is a formula that minimizes the soil brightness that is affected by spectral vegetation indices involving red and nearinfrared (NIR) wavelengths. The formula for SAVI is:

$$
S A V I=\frac{(1+L)(N I R-R e d)}{(N I R+R e d+L)}
$$

5) Enhanced Built-up and Bareness Index (EBBI). The EBBI is calculated from the image data using the following formula:

$E B B I=\frac{S W I R-N I R}{10 \sqrt{S W I R-T I R})}$.

6) Biophysical Composition Index (BCI). This uses the high albedo and low albedo of TC from the Landsat 8 images. The formula was developed by Deng \& $\mathrm{Wu}$ (2012):

$B C I=\frac{(H+L) / 2-V}{(H+L) / 2+V}$

\subsection{Index Thresholding}

Determination of the threshold value was made using the Otsu thresholding method, with the assumption that the data distribution used was reasonable (Xu et al., 2018). The selection of the normalization index was made through an accuracy test that considers the index values from -1 to 1 with the proper spatial distribution. If visually and spectrally do not accept like the pixel values are not normally distributed, the normalization index is dropped for the accuracy test stage. Image-based research is very concerned with spatial data quality (Luo et al., 2017). Consequently, the value and pixel distribution must be in line with previously developed theories. The accuracy test for the study was conducted by comparing the results of the calculation of the threshold value with the results of the field data collection from 156 samples. Thresholding is an essential part of image segmentation. The Otsu method is the most successful method for thresholding because the calculation used is straightforward (K. Li \& Chen, 2018); it uses the threshold value automatically from the segmentation method. Otsu binarization was the method used in this study to observe the contrasting differences in the object. 


\section{Results and Discussion}

\subsection{Results}

Remote sensing is very useful as a provider of spatial and temporal data. The advantage of utilizing the remote sensing index by exploiting different spectral characteristics produces new information from the highest and lowest spectral characteristics. The data extraction approach uses land cover similarity in complex ecosystems, which is analog is the same as the vegetation-impervious-soil model. Index development by combining various indexes with different wavelengths provides a different result, value, and also index information. In impervious surfaces, a single spectral difference is difficult to use. Therefore, it is necessary to consider various indices to establish the best indexes for impervious surface analysis. Bare land is a significant factor that can affect impervious surfaces.

Visual analysis and quantitative measurements emphasize the separation between vacant land and wet surfaces. The six indexes were grouped according to function, namely the built-up index, water index, and impervious surface index. The developed land index uses NDBI and EBBI, and the vegetation index uses SAVI and NDVI, and the impervious index NDISI and BCI (Figure 2). The calculation of the three classes was made to find the index that had the most extensive range of values and a more extended spectral range (Table 1). A comparison of various indexes provides an assessment of their effectiveness. Correlation analysis was also conducted to measure the relationship between the index used. NDISI is designed to maximize radiation emitted from the ground; NDISI uses thermal wavelengths and MIR wavelengths that increase sand and soil reflectance, together with minimization of water reflection by involving NIR, MIR, and visible wavelengths.

Landsat 8 OLI has advantage of SWIR 1 and SWIR 2 wavelengths; therefore, operation of both can be used optimally. The results concluded that NDISI with SWIR1 was more stable than NDISI with SWIR2. This research combined qualitative and quantitative analysis. Qualitative analysis was proposed to assess the water index, histogram distribution formed, and to assess the statistical value of the resulting index. The quantitative assessment used was correlation analysis of the various index employed.
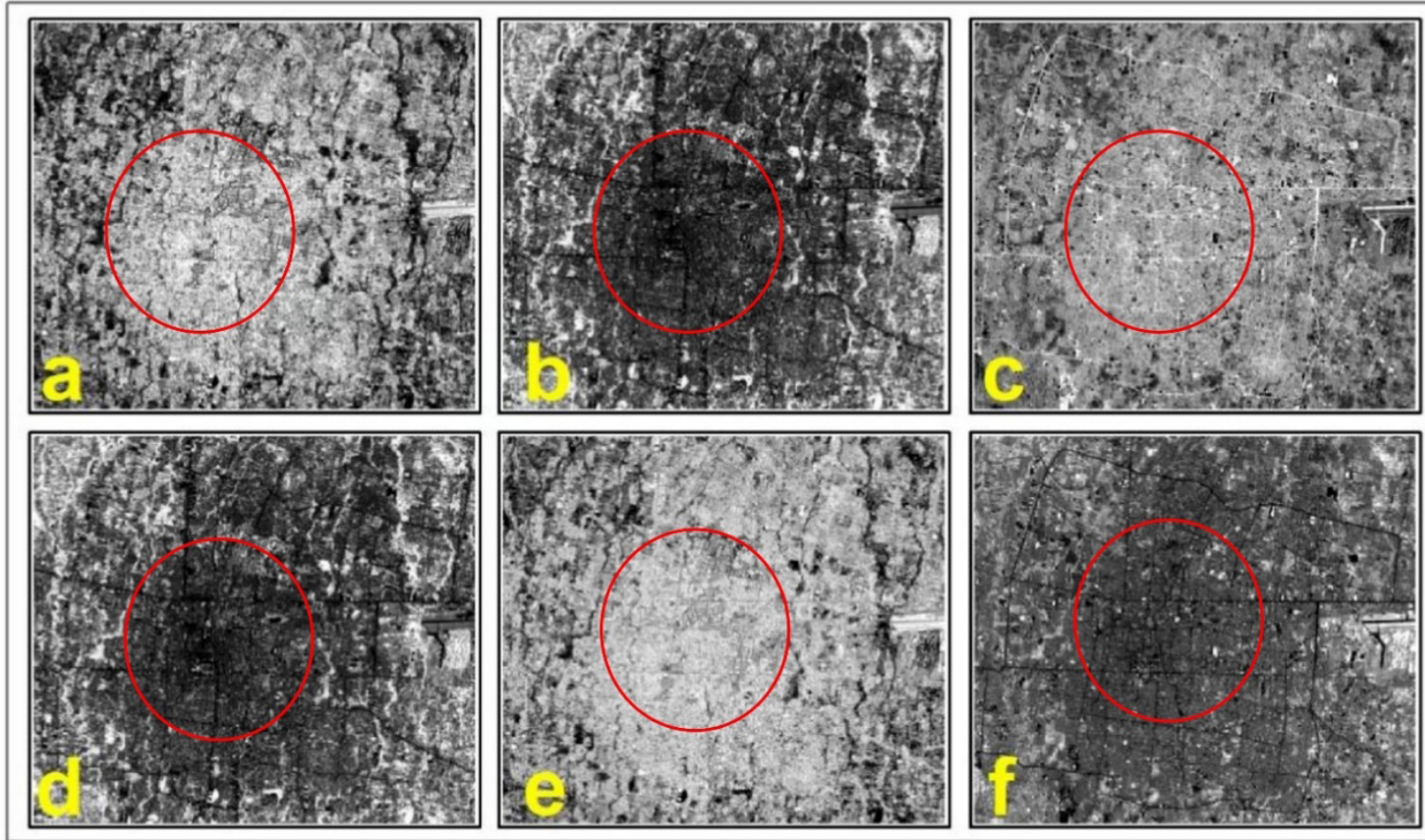

Figure 2. Comparison of the Landsat 8 OLI indices : (a) NDBI ; (b) NDVI ; (c) NDISI ; (d) SAVI ; (e) EBBI ; (f) BCI 
Table 1. Statistical value of image processing result.

\begin{tabular}{ccccc}
\hline Index & Min & Max & Mean & Standard deviation \\
\hline NDBI & -0.879418 & -0.337982 & -0.627609 & 0.074239 \\
NDVI & -0.412155 & 0.624103 & 0.098661 & 0.145405 \\
NDISI & -0.871741 & -0.249603 & -0.601646 & 0.035497 \\
SAVI & -0.608690 & 0.933012 & 0.147278 & 0.217066 \\
EBBI & -0.009445 & 0.011377 & -0.000633 & 0.001594 \\
BCI & -0.376976 & 0.081065 & -0.293511 & 0.017392 \\
\hline
\end{tabular}

Table 2. Data range of NDVI and SAVI of the Landsat 8 OLI.

\begin{tabular}{ccccc}
\hline Index & Min & Max & Size of Data Range & Standard deviation \\
\hline NDVI & -0.412155 & 0.624103 & 1.036258 & 0.145405 \\
SAVI & -0.608690 & 0.933012 & 1.541702 & 0.217066 \\
SAVI-NDVI & & & 0.505444 & \\
\hline
\end{tabular}

Table 3. Data range of NDBI and EBBI of the Landsat 8 OLI.

\begin{tabular}{ccccc}
\hline Index & Min & Max & Size of Data Range & Standard deviation \\
\hline NDBI & -0.879418 & -0.337982 & 0.54144 & 0.074239 \\
EBBI & -0.009445 & 0.011377 & 0.02082 & 0.001594 \\
NDBI - EBBI & & & 0.52061 & \\
\hline
\end{tabular}

Table 4. Data Range of NDISI and $\mathrm{BCl}$ of the Landsat $8 \mathrm{OLI}$

\begin{tabular}{ccccc}
\hline Index & Min & Max & Size of Data Range & Standard deviation \\
\hline NDISI & -0.871741 & -0.249603 & -0.60165 & 0.035497 \\
BCI & -0.376976 & 0.081065 & -0.29351 & 0.017392 \\
BCI - NDISI & & & 0.30814 & \\
\hline
\end{tabular}

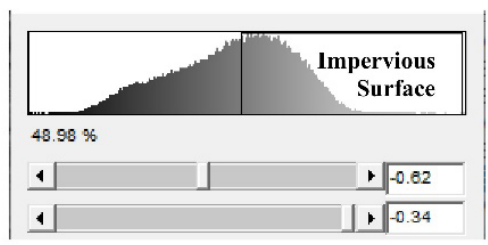

(a) NDBI

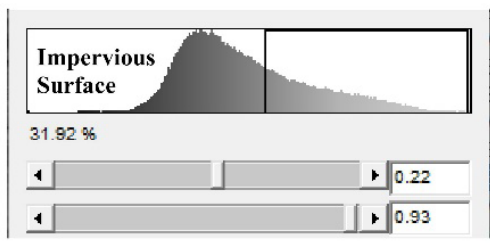

(d) SAVI

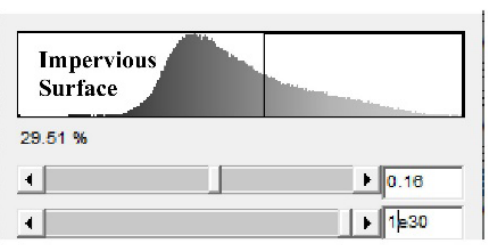

(b) NDVI

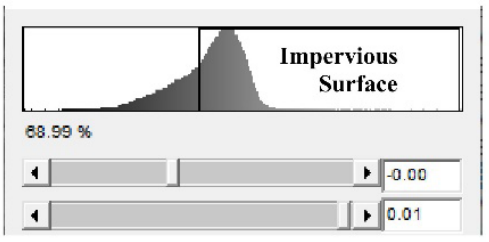

(e) EBBI

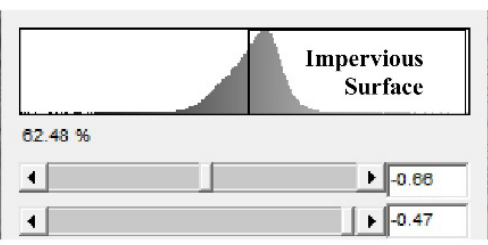

(c) NDISI

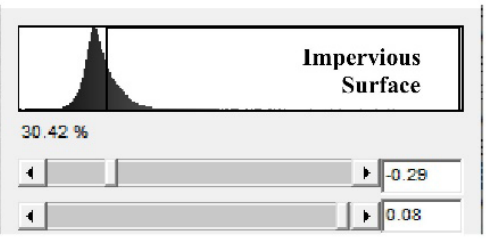

(f) $\mathrm{BCI}$

\section{Figure 3. Comparison threshold value of the various indices}

The relationship between NDVI and temporal and spatial variations in Indonesia, vegetationhasbeenexaminedinvariousstudies such as the distribution of vegetation, of vegetation, ecosystems, and microclimate, productivity, land fragmentation, ecology, both theoretically and practically. NDVI and disasters. NDVI is one way to achieve has been successfully applied in research on understanding related to the dynamics and 
distribution of vegetation to analyze the dynamics of animal populations. NDVI also has advantages in predicting environmental changes related to ecological and human impacts. It is the best index and is most often used for the extraction of vegetation data. However, it has not been able to distinguish vegetation mixed with bare-land. Huete (1988) developed SAVI to reduce this limitation by considering the background effect of vegetation, namely the soil. Consequently, the most crucial issue before choosing SAVI or NDVI has adjusted the type and characteristics vegetation in study area.

Table 2 shows the results from comparison between the statistical values of NDVI and SAVI. They demonstrate that SAVI and NDVI with three mainland uses, namely impervious surfaces, roads, and vegetation. Based on the statistical values shown, SAVI has a higher range of values when compared to NDVI. The minimum value of NDVI is -0.41 , while that of SAVI is -0.60 . The maximum value for NDVI is 0.62 , and for SAVI it is 0.933 . The difference between the two index values is 0.50 ; therefore, SAVI has a more reasonable and more accessible range value index, so it possible to distinguish between vegetation, soil, and impervious surfaces. Especially for land reflectance, SAVI has better and full ranger, meaning it provides more detailed information than NDVI.

Similar to the built land index, NDBI and EBBI were compared to establish the bulit-land index (Table 3), which is the strongest standar deviation, size of data range, and maximum values. From the statistical values displayed, NDBI has a broader range of values compared to EBBI. The distribution of urban built land in NDBI is more visible when compared to EBBI. The table shows that value of the selection between NDBI and EBBI is 0.5 and that the use of NDBI is more significant and better when compared to EBBI.

The difference between NDISI and BCI is the wavelength used. The process used in $\mathrm{BCI}$ is to combine the visible band as a component that is processed with PCA. NDISI involves TIR, $\mathrm{NIR}$, and Green wavelengths, while the $\mathrm{BCI}$ data range is more complicated than that of NDISI. PC transformation of visible band combinations of BCI makes it more flexible than NDISI for urban impervious surface analysis. Based on the resulting index in Figure 2, the spectral reflectance of bare land or soil is light-gray, with soil and vegetation shown in dark gray and black. Road patterns can be observed when using NDISI and BCI more than with NDBI and EBBI. NDBI and EBBI are superior for observing urban built land (Table 4).

Based on the threshold analysis conducted, the impervious surface area for NDBI has a range of -0.62 to -0.34 , with an impervious surface area of $48.98 \%$ (Figure 3). With reference to Table 4 , the threshold limits for each index differ in determining the impervious surface area. Qualitative analysis was made to observe the correlation between the various indices and the impervious surfaces. A total of 156 field samples were used to measure these surfaces.

\subsection{Discussion}

For every spatial scale, correlation analysis was conducted to check and investigate the correlation between $\mathrm{BCI}$ and vegetation abundance. Based on the results of the analysis made, BCI was the best index for impervious surface analysis (Deng \& Wu, 2012). To establish BCI performance, a comparative analysis with NDVI, NDBI, and NDISI was conducted. The correlation between NDVI and the impervious surfaces produced an erroneous value because the reflection of the soil was mixed with the reflection of the impervious surface. The urban built-up area and roofs of buildings were also detected as bare land and vegetation. Specifically, the appearance of vegetation, NDVI and SAVI are the best indexes to distinguish vegetation from other objects (Gonçalves, Saleem, Queiroz, \& Awange, 2019). The performance of BCI, NDISI, EBBI, and NDBI is far below that of SAVI and NDVI.

Based on the NDBI index of Landsat 8 OLI, error was detected between bare soil and impervious areas, both of which had a 
bright tone. The mixture of built and nonbuilt land makes them difficult to classify in pixels. Temperature values resulting from pixel temperatures may be mostly associated with built-up areas and the number of sites. Besides, NDBI is very responsive to built-up areas. The $\mathrm{BCI}$ index is convenient ; $\mathrm{BCI}$ can also highlight the differences between the three main urban biophysical compositions, namely vegetation, impervious surfaces, and soil, following the conceptual V-I-S model. The results show that $\mathrm{BCI}$ has an important and positive relationship with impervious surfaces in urban areas, and a relationship with vegetation and urban built-up land. $\mathrm{BCI}$ can also distinguish bare land in urban areas. Another benefit of $\mathrm{BCI}$ is that it utilizes various channels that are packaged in certain transformations to shorten and sharpen objects. It can also be applied at different resolution levels because it emphasizes visible channels in the image and does not depend on SWIR and TIR bands. Information on urban biophysical and impervious composition is essential to describe the physical condition of urban areas.

\section{Conclusion}

Information related to impervious surfaces such as its urban biophysical composition is essential for urban planning in sustainable development. $\mathrm{BCI}$ is a simple index, ie the BCI index does this considering the composition of the conceptual triangle model of vegetationimpervious surface-soil as an alternative in the mapping of impervious surfaces in urban areas. The correlation results show that $\mathrm{BCI}$ has the highest index value when compared to NDVI, NDBI, EBBI, SAVI, and NDISI. It has the highest relationship with the impervious surface, as evidenced by the most significant correlation coefficient. The study concludes that $\mathrm{BCI}$ is the most useful index for separating impervious surfaces from bare land, residential areas, and vegetation.

\section{Acknowledgments}

Our heartfelt thanks go to the Dean and Vice Dean of the Geography Faculty, Gadjah Mada University, for their support and permission for mapping and analyzing of impervious area. Our gratitude also goes to USGS for providing Landsat data.

\section{References}

Chen, X., Jia, X., \& Pickering, M. (2019). A Nighttime Lights Adjusted Impervious Surface Index (NAISI) with Integration of Landsat Imagery and Nighttime Lights Data from International Space Station. International Journal of Applied Earth Observation and Geoinformation, 83, 101889. https://doi.org/10.1016/j.jag.2019.05.022

Chen, Y., \& Yu, S. (2016). Assessment of urban growth in Guangzhou using multi-temporal, multi-sensor Landsat data to quantify and map impervious surfaces. International Journal of Remote Sensing, 37(24), 5936-5952. https:// doi.org/10.1080/01431161.2016. 1252473

Deng, C., \& Wu, C. (2012). Remote Sensing of Environment BCI : A biophysical composition index for remote sensing of urban environments. Remote Sensing of Environment, 127, 247-259. https:// doi.org/10.1016/j.rse.2012.09.009

Deng, Y., Wu, C., Li, M., \& Chen, R. (2013). RNDSI: A ratio normalized difference soil index for remote sensing of urban/suburban environments. International Journal of Applied Earth Observation and Geoinformation, 39, 40-48. https://doi.org/10.1016/j. jag.2015.02.010

Gonçalves, R. M., Saleem, A., Queiroz, H. A. A., \& Awange, J. L. (2019). A fuzzy model integrating shoreline changes, NDVI and settlement influences for coastal zone human impact classification. Applied Geography, 113, 102093. https://doi.org/10.1016/j. apgeog.2019.102093

Huang, F., Yu, Y., \& Feng, T. (2019). Automatic extraction of impervious surfaces from 
high resolution remote sensing images based on deep learning. Journal of Visual Communication and Image Representation, 58, 453-461. https://doi.org/10.1016/j. jvcir.2018.11.041

Huete, A. R. (1988). A soil-adjusted vegetation index ( SAVI). Remote Sensing of Environment, 25, 295-309. https:/ / doi.org/10.1016/0034-4257(88)90106-X

Jawak, S. D., \& Luis, A. J. (2013). A spectral index ratio-based Antarctic land-cover mapping using hyperspatial 8-band WorldView-2 imagery. Polar Science, 7(1), 18-38. https:// doi.org/10.1016/j.polar.2012.12.002

Li, K., \& Chen, Y. (2018). A Genetic Algorithm-based urban cluster automatic threshold method by combining VIIRS DNB, NDVI, and NDBI to monitor urbanization. Remote Sensing, 10(2), 1-22. https:/ / doi.org/10.3390/rs10020277

Li, L., Lu, D., \& Kuang, W. (2016). Examining Urban Impervious Surface Distribution and Its Dynamic Change in Hangzhou Metropolis, 19-24. https://doi.org/10.3390/ rs8030265

Li, Y., Gong, X., Guo, Z., Xu, K., Hu, D., \& Zhou, H. (2016). An index and approach for water extraction using Landsat-OLI data. International Journal of Remote Sensing, 37(16), 3611-3635. https:// doi.org/10.1080/01431161.2016.1201228

Liu, C., Zhang, Q., Luo, H., Qi, S., Tao, S., Xu, H., \& Yao, Y. (2019). An efficient approach to capture continuous impervious surface dynamics using spatial-temporal rules and dense Land sat time series stacks. Remote Sensing of Environment, 229, 114-132. https:/ / doi.org/10.1016/j.rse.2019.04.025

Liu, K., Su, H., Zhang, L., Yang, H., Zhang, R., \& Li, X. (2015). Analysis of the urban heat Island effect in shijiazhuang, China using satellite and airborne data. Remote Sensing, 7(4), 4804-4833. https:/ / doi.org/10.3390/rs70404804

Liu, S., Zang, Z., Wang, W., \& Wu, Y. (2019). Spatial-temporal evolution of urban heat Island in Xi'an from 2006 to 2016. Physics and Chemistry of the Earth, 110, 185-194. https:/ / doi.org/10.1016/j.pce.2018.11.007

Lu, D., Moran, E., \& Hetrick, S. (2011). Detection of impervious surface change with multitemporal Landsat images in an urban-rural frontier. ISPRS Journal of Photogrammetry and Remote Sensing, 3(66), 298-306. https://doi.org/10.1038/ jid.2014.371

Lu, D., \& Weng, Q. (2006). Use of impervious surface in urban land-use classification. Remote Sensing of Environment, 102(1-2), 146-160. https:/ / doi.org/10.1016/j.rse.2006.02.010

Luo, X., Peng, Y., \& Gao, Y. (2017). An Improved Optimal Segmentation Threshold Algorithm and Its Application in the Built-up Quick Mapping. Journal of the Indian Society of Remote Sensing, 45(6), 953-964. https:/ / doi.org/10.1007/s12524-016-0656-4

McFeeters, S. K. (2013). Using the normalized difference water index (ndwi) within a geographic information system to detect swimming pools for mosquito abatement: A practical approach. Remote Sensing, 5(7), 3544-3561. https://doi.org/10.3390/ rs5073544

Parece, T. E., \& Campbell, J. B. (2013). Comparing urban impervious surface identification using landsat and high resolution aerial photography. Remote Sensing, 5(10), 49424960. https://doi.org/10.3390/rs5104942

Phinn, S., Stanford, M., Scarth, P., Murray, A. T., \& Shyy, P. T. (2002). Monitoring the composition of urban environments based on the vegetation-impervious surface-soil (VIS) model by subpixel analysis techniques. International Journal of Remote Sensing, 23(20), 4131-4153. https:// doi.org/10.1080/01431160110114998 
Sharma, R., Ghosh, A., \& Joshi, P. K. (2013). Spatio-temporal footprints of urbanisation in Surat, the Diamond City of India (1990-2009). Environmental Monitoring and Assessment, 185(4), 3313-3325. https:/ / doi.org/10.1007/ s10661-012-2792-9

Shirani-bidabadi, N., Nasrabadi, T., Faryadi, S., Larijani, A., \& Shadman Roodposhti, M. (2019). Evaluating the spatial distribution and the intensity of urban heat island using remote sensing, case study of Isfahan city in Iran. Sustainable Cities and Society, 45, 686-692. https:// doi.org/10.1016/j.scs.2018.12.005

Sinha, P., Verma, N. K., \& Ayele, E. (2016). Urban Built-up Area Extraction and Change Detection of Adama Municipal Area using Time-Series Landsat Images, 5(8), 18861895.

Sunde, M. G., He, H. S., Zhou, B., Hubbart, J. A., \& Spicci, A. (2014). Imperviousness Change Analysis Tool (I-CAT) for simulating pixel-level urban growth. Landscape and Urban Planning, 124, 104-108. https:// doi.org/10.1016/j.landurbplan.2014.01.007

Trivero, P., Biamino, W., Borasi, M., Cavagnero, M., Musa, M., Rinaudo, C., \& Sesia, V. (2012). An air quality balance index estimating the total amount of air pollutants at ground level. Environmental Monitoring and Assessment, 184(7), 4461-4472. https:// doi.org/10.1007/s10661-011-2278-1

Walker, J. J., De Beurs, K. M., \& Wynne, R. H. (2014). Remote Sensing of Environment Dryland vegetation phenology across an elevation gradient in Arizona, USA, investigated with fused MODIS and Landsat data. Remote Sensing of Environment, 144, 85-97. https:/ / doi.org/10.1016/j.rse.2014.01.007

Weng, Q. (2012). Remote Sensing of Environment Remote sensing of impervious surfaces in the urban areas : Requirements, methods, and trends. Remote Sensing of Environment, 117, 34-49. https:// doi.org/10.1016/j.rse.2011.02.030

Weng, Q., \& Lu, D. (2008). A sub-pixel analysis of urbanization effect on land surface temperature and its interplay with impervious surface and vegetation coverage in Indianapolis, United States, 10, 68-83. https://doi.org/10.1016/j.jag.2007.05.002

Wu, X., Zhang, L., \& Zang, S. (2019). Examining seasonal effect of urban heat island in a coastal city. PLoS ONE, 14(6), 1-16. https:// doi.org/10.1371/journal.pone.0217850

Xian, G., Shi, H., Dewitz, J., \& Wu, Z. (2019). Performances of WorldView 3, Sentinel 2, and Landsat 8 data in mapping impervious surface. Remote Sensing Applications: Society and Environment, 15, 100246. https://doi.org/10.1016/j.rsase.2019.100246

Xiao, X. D., Dong, L., Yan, H., Yang, N., \& Xiong, Y. (2018). The influence of the spatial characteristics of urban green space on the urban heat island effect in Suzhou Industrial Park. Sustainable Cities and Society, 40, 428-439. https://doi.org/10.1016/j. scs.2018.04.002

Xu, H. (2006). Modification of Normalized Difference Water Index ( NDWI ) to Enhance Open Water Features in Remotely Sensed Imagery. International Journal of Remote Sensing, 27, 3025-3033. https:// doi.org/10.1080/01431160600589179

Xu, R., Liu, J., \& Xu, J. (2018). Extraction of high-precision urban impervious surfaces from sentinel-2 multispectral imagery via modified linear spectral mixture analysis. Sensors (Switzerland), 18(9), 1-15. https://doi.org/10.3390/s18092873

Zhang, H., Lin, H., Li, Y., Zhang, Y., \& Fang, C. (2016). Mapping urban impervious surface with dual-polarimetric SAR data : An improved method. Landscape and Urban Planning, 151,55-63. https:/ / doi.org/10.1016/j.landurbplan.2016.03.009

Zhang, L., \& Weng, Q. (2016). Annual dynamics of impervious surface in the Pearl River Delta, China, from 1988 to 2013, using time series Landsat imagery. ISPRS Journal 
of Photogrammetry and Remote Sensing, 113, 86-96. https://doi.org/10.1016/j. isprsjprs.2016.01.003

Zhang, X., Estoque, R. C., \& Murayama, Y. (2017). An urban heat island study in Nanchang City, China based on land surface temperature and social-ecological variables. Sustainable Cities and Society, 32, 557-568. https:/ / doi.org/10.1016/j.scs.2017.05.005 